\title{
Reflections on Environmental Concern and Sustainability Manifested in the Selected Works of the 14th Dalai Lama
}

\author{
Maria Luisa A. Valdez, Ph.D. \\ Batangas State University, Philippines
}

\author{
*Corresponding Author: Maria Luisa A. Valdez, Ph.D., Batangas State University, Philippines
}

\begin{abstract}
The contemporary world faces considerable unparalleled environmental crises. Declining of the Earth's environment gradually threatens the natural resource base and processes whereupon all life on earth depends. Without resilient and multifaceted action by all humanity, the environment may not be able to sustain human life. Thus, this qualitative study was conducted to analyze the reflections on environmental concern and sustainability manifested in the selected literary pieces of His Holiness, the 14th Dalai Lama, pointing out the events and situations which show the teachings on ecological stewardship that may benefit the students. Findings of the analysis revealed that the selected works consider the direct relationship of man to his environment, clearly outlining a simple solution that will serve as man's focal point in resolving global ecological problems and the attainment of a sustainable ecosystem, particularly the awareness of each and every individual to Mother Nature's needs. Ecological concerns were reflected in the selections in terms of appreciating Earth's bounty and beauty, respecting Earth and life in all its diversity, caring for community life, and safeguarding Earth's regenerative capacities. Likewise, ecological sustainability was manifested in the author's works with regard to reconciliation of environmental demands, social equity demands and economic demands. Teachings on ecological stewardship which shall benefit students were also drawn from the author's works. Taking into account each and every insight provided by the writer, it is therefore important to give emphasis to the spiritual conditioning required for every person to achieve the necessary level of awareness for the author's insights to serve their purpose and imbibe the author's spirit and carry forward his legacy by practicing daily the pro-environment principle.
\end{abstract}

Keywords: Ecological Concern, Environmental Stewardship, His Holiness the 14th Dalai Lama, Sustainability

\section{INTRODUCTION}

A global ecological crisis looms over mankind as the deterioration of Planet Earth's environment increasingly threatens the natural resource base and the processes upon which all life on earth depends. With warning signs coming in the form of natural disasters, the odds are not in favor of mankind. As environmental problems continue to mount, mankind is left vulnerable to tragedy and the world on the verge of a total collapse. The irony is in the fact that as humans strive toward greater prosperity, present-day Earth is telling them a different story that hints of an impending doom unless a critical assessment of their previous mistakes is made and urgent action taken.

Sadly, the act of hauling people out of poverty and into the technologically advanced world often comes at the expense of the local environment. With visions of much-improved living conditions and a promising future for the human race, it is understandable for decision-makers and leaders to be keen on taking advantage of technological breakthroughs and cost-cutting methods of production in order to be competitive in the ever-expanding global market. However, such efforts directed toward industrial growth have major implications for the environment, as exemplified by infrastructural developments that result in pristine terrains all over the world being altered in the most devastating manner. Humankind primarily must bear the brunt of the cumulative effects of environmental degradation as all of existence depends on the planet's ecosystem. Considering the aforementioned conditions for survival, anything that can be considered an environmental threat therefore threatens human existence [1].This inconvenient truth has put the planet Earth in its unbalanced state.

This is true for many countries around the world but is explicitly serious in Southeast Asian nations, as their economies, especially the tourism sector, depend so fundamentally on untouched natural resources. Many of the world's most challenging environmental issues, like air pollution, endangered 
species conservation, deforestation, destruction of coral reefs, water security, and increased urbanization, beset this region. These issues are inseparably linked, and working to upgrade one will often benefitor positively impact the others.

Sharing the same challenges is the Republic of the Philippines, which is one of several countries most adversely affected by environmental problems. The country is now beset with the situation of a deteriorating natural environment as an ill effect of a rapidly expanding growth in the populace, deforestation, erosion, diminishing agricultural terrain, polluted air and water from erratic methods of solid and toxic waste disposal, and destruction of coral reefs, resulting from abusive practices in fishing and the total mismanagement of the majority of the country's coastal resources [2].

Cognizant of the fact that most environmental problems are trans boundary, regional or global in scope, it is but fitting for all countries and their stakeholders to work together extensively and gradually to solve these problems. Without resilient and multifaceted action by all humanity, the environment may not be able to continue to sustain human life. Future generations may suffer scarcity and adversity unless current patterns of production, consumption and waste management intensely change. Moreover, the determination to balance the desire for progress with the need to care for the Earth's support systems is increasingly being acknowledged. Thus, it is but timely for humanity to act upon this responsibility.

Although dreadful environmental conditions and the struggle for scarce resources are potential sources for conflict, history has recurrently shown that these circumstances are more often facilitators for cooperation. Problems of shared resources regularly produced shared solutions. Humanity, in general, is capable of providing its full and rightful support for peace and world stability.

With reference to this, the founding of the United Nations Environment Programme (UNEP) as environmental guardians under the umbrella of the UN system along with the 2012 Rio+20 Outcome Document is dedicated to "[promoting] the coherent implementation of the environmental dimension of sustainable development within the UN system and to [serving] as an authoritative advocate for the global environment" [3].

The ever-unpredictable changes in the planet's climate, together with the working class woes of underemployment or unemployment and the total imbalance in opportunities leading to scarcity of food and resources all voice the need to arrest the root cause of the world's problems: the need for a total makeover. Stepping up to the plate, the UN system is expected to accept the challenge of blueprinting a sustainable environmental program that promises an equal share of progress and prosperity for everyone without transgressing the planet's ecological boundaries. It is vital for the United Nations to uphold the rebuilding of Earth's ecosystem by providing a well-balanced helping hand to countries in order to fast-track an integrative implementation of the socioeconomic and environmental dimensions of the 2030 Agenda for Sustainable Development. Relative to this,as mandated by the UN system, it is within the commitment of UNEP to cooperate with those concerned to push for the implementation and realization of the Sustainable Development Goals (SDGs). Likewise, the promotion of a sustainable environment serves as UNEP's directive to implement the SDGs and secure the planet's health. Integrated within the UNEP's mandate of providing worldwide support en route to sustainable development and building acountry's capacity to monitor progress is the foremost consideration of a healthy environment [4].

Taking note of the degree of similarity between literature and human societies, readers are convinced that literature is not just a social construct which is rooted in mere ideas, imaginations or imaginary situations. Rather, it is a social institution and a form of tradition, which has existed for a long time and is accepted as an essential component of a given society to perform certain functions. Readers can view literature as a social reality, which portrays the state of things as they are, rather than as they are imagined to be. Hinged on the premise that if literature will be viewed from a sociological perspective, it can then serve as a motivational tool for people to cooperate in the dissemination of information that is necessary to fulfill the collective goal of national reconstruction. Indeed, there is a distinct relationship between literature and the milieu or environment where and when it was written with the aim of carrying out some germane functions like dissemination of information. It remains an instrument for positive social changes. In a nutshell, it is a panacea for human peaceful co-existence and sustainable developments [5]. 
As stated earlier, the Planet Earth is currently experiencing a climate crisis and this harsh and hostile reality has drawn the profound attention of many writers who concern themselves with ecological issues. One of those writers is His Holiness, the $14^{\text {th }}$ Dalai Lama, Tenzin Gyatso.

His Holiness, the 14th Dalai Lama came from a family of farmers in Taktser, Amdo, northeastern Tibet. Born Lhamo Thondup, he was renamed Jetsun Jamphel Ngawang Lobsang Yeshe Tenzin Gyatso upon recognition at the age of two as the reincarnation of the 13th Dalai Lama, Thubten Gyatso. In accordance with Tibetan tradition, the world's foremost Buddhist leader Tenzin Gyatso is presently at the spiritual helm of Tibet.

The Dalai Lamas are regarded by Tibetan Buddhist followers as the manifestations of the Great Buddha of Compassion, who have all undergone a spiritual rebirth prior to dedicating a lifetime of service to humanity. The Tibetans consider the Dalai Lamas as spiritual leaders and hold them in the highest of regard, as "Dalai Lama" means "Ocean of Wisdom". His Holiness, the $14^{\text {th }}$ Dalai Lama is referred to by contemporary Tibetans as "Yizhin Norbu", which translates to "The Wish-Fulfilling Gem," or at times, as "Kundun," which simply means "The Presence"[6].

A man of peace, His Holiness, the 14th Dalai Lama was awarded The Nobel Peace Prize in 1989 for his relentless call for a non-violent liberation of Tibet. The Norwegian Nobel Committee gave emphasis to Dalai Lama's consistency in proposing peaceful, proactive and constructive solutions for international conflicts, human rights violations and worldwide environmental issues, recognizing the awardee's philosophy which comes from a deep respect and love for all beings, as well as his ideology of a universal responsibility which governs mankind and nature altogether [6]. Likewise, he became the first Nobel Laureate to be recognized for his concern for global environmental problems [7].According to Jacobs (2011) [6], Dalai Lama is a fervent and zealous advocate in calling for a recognition of the need for preserving the environment, in consideration of the role of the planet's ecology in relation to its well-being. His passion in caring for all sentient beings which encompasses humanity as well as all flora and fauna transcends national boundaries. He has successfully endeared himself to the rest of the world, exemplifying humility and wisdom in the midst of Tibet's longstanding ordeal of Chinese occupation.

His Holiness upholds being guided by three major commitments: promoting basic human values or secular ethics in consideration of human happiness, fostering harmony among various religions, and the preservation of Tibetan culture, religion and identity, thus securing the welfare of its people. He is able to incorporate the central tenets of Buddhist philosophy with much clarity and thought-provoking eloquence, being a superior scholar well-versed in the classical texts of the Nalanda Tradition of Indian Buddhism, on top of his innate gift for pedagogy, augmented by his radiant and cheerful disposition. He has successfully bridged the gap between Buddhist teachings and science by his contemplative, well-thought-out modern investigative techniques, presenting a new perspective on ancient tools of insightful wisdom in the face of today's problems. He is unwavering in his attempts to foster dialogue among world leaders with his vision of a world where disparities in beliefs do not stand in the way of global harmony [8].

The $14^{\text {th }}$ Dalai Lama has extensively travelled to various countries to date, spreading his ecumenical message of global understanding, equity in compassion and kindness towards fellow human beings, and calls for a passionate effort for greater environmental respect and world peace [6].

This study is anchored on Ehrlich's and Raven's Society-Nature Coevolution Theory. This theory focuses on the dynamic mutual interactions between human societies and their natural environment. In His Holiness' works, he underscored the interrelationship or interdependence between the natural environment and the sentient beings living within it. He is one of the world's advocates of environmental stewardship. Through His Holiness' writings, readers may glean that literature can be a writer's channel for conveying environmental stewardship at a philosophical level.

The significance of this literary analysis is highlighted in terms of its importance to the academic managers, working professionals, college instructors of literature, students of literature, researchers, and future researchers. This study will help the academic managers to ensure that environmental concern and sustainability initiatives are integrated in the academe by inspiring them to spawn proenvironment-related activities in the curricula that will educate the academic community on the beneficial outcomes of a sustainable planet Earth. This paper will likewise be beneficial for the 
working professionals to organize and support ecological stewardship in their workplaces to address environment issues. Moreover, the analysis will inform the College literature instructor's methodology in teaching literature as a discourse, specifically when dealing with the appropriate literary theories, approaches and themes in literary analysis. This study will give the students of literature an extensive and profound outlook on the importance of the environment and may lead them to study and appreciate His Holiness' eloquently written books, which convey his entire message to the world in considerable length, with gravity, wit and literary skill as well as inspire them to engage in literary analysis as an academic undertaking. The researcher will be benefitted by this study through the treatment of materials and analysis, and through the careful investigation of the themein the literary genres. Likewise, this paper will enlighten them on the process of drawing out literary theories and utilizing critical approaches in literary analysis. And finally, this paper may motivate them to conduct more studies on ways that are most effective in integrating the environmental concern and sustainability into the people's psyche to substantiate the present investigation.

Bearing these thoughts in mind, the researcher, who is a lecturer of English at the Batangas State University, is deeply motivated to explore and undertake an analysis of how ecological concern and sustainability is reflected in His Holiness, the $14^{\text {th }}$ Dalai Lama's selected works and gain teachings on ecological stewardship that would benefit the students.

\subsection{Objectives of the Study}

This study analyzed ecological concern and sustainability reflected in the selected literary works of His Holiness, the $14^{\text {th }}$ Dalai Lama pointing out the teachings on ecological stewardship which shall benefit the students. Likewise, this paper presented the reflections of the author on the environment that may be gleaned from the selections; the ecological concern reflected in the works in terms of respecting Earth and life and all its diversity, safeguarding Earth's regenerative capacities, caring for community life, and appreciating Earth's beauty and bounty; and sustainability manifested in the selections with regard to reconciliation of environmental demands, social equity demands and economic demands.

\subsection{Method and Materials}

\subsubsection{Research Design}

The study employed the qualitative method of research in analyzing the $14^{\text {th }}$ Dalai Lama's concept of environmental concern and sustainability in the representative literary works chosen. Qualitative research, according to Suter (2012) [9], must adhere to the philosophy that the realities experienced by readers in understanding the complexity of a phenomenon must be taken in consideration. The reader's various realities can be manifested in a variety of ways which include the genres of literature that are known as essays and speeches or discourses. Philosophical and moral approaches were used as the bases for analysis.

Human experiences are defined by social, cultural and political influences, hence, human experiences are intertwined with the said concepts, according to Ary, et al. (2006) [10]. Therefore, the principles in the context of a Buddhist builder of peace were considered in the analysis of the identified works of literature, as these provide substantial and significant insights on the author's motivations with regard to his core principle.

Patton (2002) [11] stated that qualitative data analysis aims to point out the emergence of themes, concepts, patterns and insights, hence, this research likewise utilized textual analysis, a systematic technique in message handling and context analysis [12]. Qualitative data analysis in this study was therefore focused on seeking patterns and extracting insights from the 14th Dalai Lama's selected literary narratives or image data.

\subsubsection{Treatment of Materials}

The essential features in the treatment of materials were considered in the conduct of this study. To adopt a more systematic identification of the selected works that fits literary standards, the seven criteria cited by Stott (2014) [13] were adhered to. These are the standards as regards what a piece of literature should abide to in order to be considered for analysis. The said standards include intellectual value, spiritual value, universal appeal, permanence, suggestiveness, artistry and style. 
With reference to intellectual value, the worth connected to the stimulating influence of great literature was considered. The selections can help the readers understand their lives and realize truths about humanity and life in general. They likewise stimulate the readers mentally and enrich their thoughts on a particular tenet. In relation to spiritual value, the quality of great literature which elevates the spirit was taken into consideration during the selection process. The chosen representative literary works are thought to have an underlying moral message that can potentially make the readers better people. These moral values are often written between the lines and can help the readers become better persons. As regards universal appeal, the thought that great literature appeals to all people regardless of race, creed, nationality or beliefs was taken into consideration. The said literary pieces appeal to a range of people across different age groups, nationalities, cultures and beliefs. In connection with permanence, the quality that great literature endures was also considered. The selected prose's and poems' appeal is lasting and they can be read several times as each reading gives fresh delight and new insights and opens new worlds of meaning and experience. With regard to suggestiveness, the value associated with the emotional power of great literature was noted. The selected literary pieces can carry many associations that lead beyond the surface meaning. The reader is left to establish what the author is suggesting and this captures the readers' imagination by making them think about what they are reading and engaging them into the story or poem. Relative to artistry, the quality which appeals to the readers' sense of beauty was likewise noted in the choice of representative works. The chosen works are well-written and they appeal to the readers' creative sides with beautifully crafted phrases and sentences. Finally, with reference to style, the peculiar way in which the author sees life, forms his ideas and how he expresses them were considered too. The selected literary pieces are marked with the writers' view of the world and can put thoughts to the readers in a way they have never considered.

Applying these standards, the following literary works of His Holiness were analyzed: Mother Sentient Being (2005), A Clean Environment is a Human Right (1990), Thinking Globally: A Universal Task (1999), Universal Responsibility and the Environment (1990),A Buddhist Concept of Nature (1992), An Ethical Approach to Environmental Protection (1987), Ecology and the Human Heart (1990), The Natural World (1999), An Essay on the Mountains (1992),Universal Responsibility \& the Global Environment: An Environmental Summit (2013),Caring for the Earth (1991),Politics and Environment: An Interview (2007),Universal Responsibility \& the Global Environment (1992),A Clean Environment is a Human Right (1990), Science, Spirituality and Environment (2005), and His Holiness Join 270 Religious Leaders to Sign Interfaith Climate Statement (2016). These statements and speeches delivered by His Holiness, the $14^{\text {th }}$ Dalai Lama on various occasions from 1986 up to 2017 were compiled in the book titled His Holiness, the 14th Dalai Lama on Environment-Collected Statements 1987-2017.This collection of speeches serves as a source of inspiration to all those who are interested in environmental issues and global ecological solutions. These works constituted the primary resource materials of the study.

Other literary works of His Holiness which have undertones of ecological concern and sustainability were not included in the study. Other approaches in literary criticism such as sociological and cultural approaches that may be employed in the study were also not included in the analysis.

The text analyses centers on pattern seeking and the extraction of meaning from the writer's works. This study was supported by the researcher's analysis and insights with reference to the content of the selected texts to bring about the philosophical and moral treatment of the identified works. Substantial effort was focused on the task of recording texts or making notes through concepts and categories; altering or creating subtle categories; linking and combining abstract concepts; extracting the essence; organizing meaning; writing an understanding; and drawing conclusions.

\subsection{Results and Discussions}

\subsubsection{The Author's Reflections on the Environment as Gleaned in the Selections}

His Holiness the $14^{\text {th }}$ Dalai Lama is known for the lessons and teachings in his works, all of which were intended to inspire his readers or audience to reflect on the messages contained within. It is worth mentioning, that as an author, a part of Tenzin Gyatso's teachings include reflections on the environment, and in order to better understand his insights as gleaned in the selections, it is important to consider his perspective as a Buddhist and as a Tibetan. He recalled that 
Prior to the Chinese invasion, Tibet was a fresh, beautiful, unspoiled wilderness sanctuary in a unique natural environment.

[In Tibet] There are other kinds of traditions and values- values that attach importance to compassion and respect to all forms of life. (Mother Sentient Being, 2005) [14]

Moreover, in keeping with the Tibetan way of life, His Holiness, the $14^{\text {th }}$ Dalai Lama advocated for a sanctuary for all living beings. How he valued the environment is based on a way of life that is strongly influenced by his Buddhist faith. He cited that the

Tibetans have a great respect for all forms of life. This inherent feeling is enhanced by our Buddhist faith, which prohibits the harming of all sentient beings, whether human or animal. (A Clean Environment is a Human Right, 1990) [15]

With this insight, it is noteworthy to mention that while the distinct characteristic of a Tibetan's attitude towards the environment was epitomized by the Dalai Lama, he also refers to the current global situation and its implications for Mother Earth, remarking on the undesirable impact of human beings' mismanagement. Indeed, Mother Earth is warning human beings that there are limits even to her tolerance.

In this century we have seen enough war, poverty, pollution, and suffering. According to Buddhist teaching, such things happen as the result of ignorance and selfish actions, because we often fail to see the essential common relation of all beings. The earth is showing us warnings and clear indications of the vast effects and negative potential of misdirected human behavior. (Thinking Globally: A Universal Task, 1999) [16]

Furthermore, the author underscored the attitude of the Tibetan Buddhist, one that understands their relationship with the natural environment, and the connection between having a feeling of well-being and showing concern for the environment, which is anchored on compassion. He also emphasized the feeling of contentment hinged on the avoidance of indiscriminate consumption of the planet's resources. He clarified that

We Buddhists express compassion for all sentient beings... The Tibetan Buddhist attitude is one of contentment, and there may be some connection here with our attitude toward the environment. We don't indiscriminately consume. We put a limit on our consumption. We admire simply living and individual responsibility. We have always considered ourselves as part of our environment, but not just any part. (Universal Responsibility and the Environment, 1990) [17]

The $14^{\text {th }}$ Dalai Lama, as both Tibetan and a Buddhist, teaches that Mother Earth, as home to all human beings, must be taken care of and they, as inhabitants of the planet, can protect their environment by showing compassion towards one another.

If people begin to act with genuine compassion for everyone, we can still protect each other and the natural environment. This is much easier than having to adapt to the severe and incomprehensible environmental conditions projected for the future. (Thinking Globally: A Universal Task, 1999) [16]

Likewise, His Holiness cited another significant reflection. In this case, it is not a question of morality or ethics, but a question of understanding the long-term benefit over short-term gain, and how this is relative to humankind's ultimate survival. He highlighted that

Not only this generation, but for other generations, the environment is something very important. If we exploit the natural environment in an extreme way, today we might get some other benefit but in the long run we ourselves will suffer and other generations will suffer. So when the environment changes, climatic conditions also change. When it changes dramatically, economic structures and many other things also change - even our physical body. So you can see the great effect from that change. (A Buddhist Concept of Nature, 1992) [18]

These reflections on the environment gleaned in the selected works of His Holiness, the 14th Dalai Lama expound not only a question of humankind's own survival but also of all the sentient beings 
living on the planet. This may be attributed to his belief that after years of Mother Earth being tolerant to the inconsistent habits of humans as regards the environment, the planet is now showing warning signs that all human beings should be aware of. Mother Earth is now reminding people that they should be serious about taking care of the planet. So, their awareness of reality should force them to think in a more comprehensive, more holistic, and a more compassionate way. His Holiness, the 14th Dalai Lama believes that people must reflect on the true nature of their interrelationship with Mother Earth. The planet is not a resource for humankind to exploit as they wish. It is a sacred inheritance and a precious home, which humankind must protect, conserve and preserve. Therefore, in order to succeed in the protection, conservation and preservation of the natural environment, initially, His Holiness considers the implication of bringing about internal balance within human beings themselves. Since negligence of the environment - which has resulted in great harm to the human community -has been brought about by their failure to truly understand its importance.

\section{Environmental Concerns Reflected in the Selected Works of His Holiness the 14TH DALAI LAMA}

His Holiness, the $14^{\text {th }}$ Dalai Lama highlighted his environmental concern in much of his teachings, showcasing a multi-faceted approach in translating his knowledge of the basic principles that humans must understand in order to safeguard the ecosystem and prolong the survival of both the planet Earth and its inhabitants' existence. His teachings on environmental concern can be summarized in terms of appreciating Earth's bounty and beauty, respecting life in all its adversity, caring for community life, and safeguarding Earth's regenerative capacities.

\subsection{Environmental Concern in Terms of Appreciating Earth's Bounty and Beauty}

First and foremost, the $14^{\text {th }}$ Dalai Lama outlined his teachings on ecological concern with his statement on humankind's ability to appreciate Earth's bounty and beauty. To start off, he stated that

Our ancestors viewed the earth as rich and bountiful, which it is. Many people in the past also saw nature as inexhaustibly sustainable... (An Ethical Approach to Environmental Protection, 1987) [19]

He gave emphasis to a Buddhist teaching that the earth as a natural environment has a fate that is intertwined with and co-dependent on its inhabitants. He underscored that

According to Buddhist teachings, there is a very close interdependence between the natural environment and the sentient beings living in it. (Ecology and the Human Heart, 1990) [20]

With this, the author reminds readers that humans must have an understanding of the interdependence of all living beings, and with this knowledge must come an appreciation of the Earth's bounty and beauty.

It is no exaggeration to say that the Tibet I grew up in was a wildlife paradise. Every traveler who visited Tibet before the middle of the twentieth century remarked on this.

Animals were rarely hunted, except in the remotest areas where crops could not be grown... As a young man, I recall seeing great numbers of different species whenever I travelled outside Lhasa. My chief memory of the three-month journey across Tibet from my birthplace at Takster in the East to Lhasa, is of the wildlife we encountered along the way. (The Natural World, 1999) [21]

This concern may be attributed to His Holiness, the $14^{\text {th }}$ Dalai Lama's perceptions and appreciation of Earth's bounty and beauty, and to his conviction that people can share the earth and take care of it together, rather than trying to possess it, which may eventually destroy the beauty of life in the process. He believed that it is essential for humanity to realize the need to have a deeper knowledge of the Earth's ecosystem in relation to its inhabitants and vice versa. Thorough study on this subject may help humankind understand the relationship of species with one another, in accordance with the requirements of the planet's ecology. By being educated in terms of the environmental processes that govern global ecology, people may be able to come up with solutions to contemporary problems through a collective and unified effort directed at preserving the planet. All of these, according to the author, will stem from a genuine recognition of the planet's bounty and beauty. 


\subsection{Environmental Concern in Terms of Respecting Earth and Life in All Its Diversity}

As can be gleaned in the selected literary pieces, environmental concern in terms of respect for Earth and life in all its diversity is anchored on compassion. His Holiness, the 14th Dalai Lama cited that since time immemorial, Tibet is a land especially blessed by Chenre-zig, the Boddhisatva of Compassion, and that all Buddhist teachings and traditions lay emphasis on the importance of Mahakaruna or Great Compassion. He mentioned that

For over 1,000 years we Tibetans have adhered to spiritual and environmental values in order to maintain the delicate balance of life across the high plateau on which we live. Inspired by the Buddha's message of non-violence and compassion and protected by our mountains, we have sought to respect every form of life, while our neighbors lived undisturbed (An Essay on the Mountains, 1992) [22]

Moreover, he added People who believe in the rights of all sentient beings should also care for the rights of other sentient beings on this planet. As followers of the Boddhisatvayana School of Buddhism, we believe that all sentient beings have served us as our mothers at one point of time in our previous lives. In fact, we simply describe them as "mother sentient beings". Therefore, we must show respect to all forms of life in the same way we do to our own mother. (Mother Sentient Being, 2005) [14]

This environmental concern may be ascribed to His Holiness' perception of the Tibetans as people who have great respect for all forms of life. This inherent value is enhanced by his Buddhist faith, which prohibits the harming of all living beings, whether human or animal.He has confidence in people that they should extend this attitude of concern to the whole environment. As a basic principle, he believes that it is better for people to help the environment if they can, and if they cannot help, at least they should try not to do harm to it. The planet Earth is humankind's mother and home. He believes that people must show respect to all life forms in the same way they do to their own mothers. It is vital to educate people and highlight the importance of respect for all life forms. This is a suitable guide when there is so much yet to understand about the complex interrelations of diverse and unique ecosystems. This outlook is anchored on His Holiness' second facet of ecological concern, which is rooted in the duty of humans to respect Earth and life in all its diversity.

\subsection{Environmental Concern in Terms of Caring for Community Life}

Another important facet of environmental concern gleaned in His Holiness, the $14^{\text {th }}$ Dalai Lama's work is his insight on caring for community life. As part of the author's aforementioned teachings on ecology, this facet can be derived from the previously mentioned section. It can be understood that with respect for Earth and life in all its diversity there follows a concern or care for community life. In one of his writings, he reminisced that

As a boy studying Buddhism, I was taught the importance of a caring attitude toward the environment. Our practice of non-violence applies not just to human beings but to all sentient beings. (Universal Responsibility and the Environment, 1990) [17]

His Holiness stated in one of the selections that caring for community life is closely associated with the humankind's ability to coexist in harmony with other living beings. He repeated one of the unique concepts of Buddhist philosophy, that of the interdependency or interconnectedness of all things. He averred that

Interdependency or interconnectedness in which I believe. That concept is from Buddhist tradition but it is applicable in every field like economy, environmental issues or global issues.

The reality is that everything is interdependent. (Universal Responsibility \& the Global Environment: An Environmental Summit, 2013) [23]

Moreover, he stressed the point that in addition to interdependence, human beings must also consider Earth as their heritage to future generations, and as the life-source of the present and future generations. Therefore, over-exploitation of the Earth's natural resources undermines the very existence of humanity. He cited that

The earth is not only the common heritage of all humankind but also the ultimate source of life.

By over-exploiting its resources we are undermining the very basis of our own life. All around, 
signs abound of the destruction caused by human activity and of the degradation of nature. Therefore, the protection and conservation of the earth is not a question of morality or ethics but a question of our survival. How we respond to this challenge will affect not only this generation but also many generations to come. (Caring for the Earth, 1991) [24]

This concern may be attributed to His Holiness' perception of the interrelationship or interdependence between the natural environment and the sentient beings living within it. According to the Buddhist teaching, there is a very close interdependence between the living beings and the natural environment. He believed that ignorance of interdependence has not only harmed the natural environment, but human society as well. Interdependence, he stressed, is a fundamental law of nature. Not only a great number of life forms but also the subtlest level of material phenomena is governed by interdependence. Likewise, this concern may be ascribed to the author's disagreement relative to the exploitation of the environment in extreme ways, and which extends to the Earth's human descendants, the future generations who will inherit a vastly degraded planet. Furthermore, he believed that the inevitable environmental problems this would cause locally could so easily turn into a catastrophe of global proportions. Not only living generations, but also future generations are threatened. Humankind must reflect on the true nature of their interrelationship with Mother Earth. It is not a resource for them to exploit at their will. It is a sacred inheritance and a precious home which they must protect. It is in this light that the author deems it of utmost importance for people to be educated about caring for community life.

\subsection{Environmental Concern in Terms of Safeguarding Earth's Regenerative Capacities}

The fourth equally important teaching of His Holiness, the 14th Dalai Lama is about ecological concern in terms of safeguarding Earth's regenerative capacities. In the following passages, he highlighted the need for industry to adapt by using new technologies without destroying the industry itself and the economy dependent on it. It's vital that Mother Earth is given the chance to regenerate or replenish herself. He stated that

New techniques are evolving so that we can avoid pollution without changing the process of industry or the economy. During a recent visit to Stockholm, my friends told me that ten years before the fish had practically disappeared from the nearby river. Now they are regenerating, simply because the industrial plants along that river have made some effort to protect the environment. In other words, they managed to improve the situation without destroying the industry. (Politics and Environment: An Interview, 2007) [25]

He continued by citing his experience when he went to the Rohr region in Germany, a center of industry

One large company showed me a film on the different means they were taking to reduce pollution and recycle waste material. Without changing their entire structure, they were causing much less damage to the environment. (Politics and Environment: An Interview, 2007) [25]

$\mathrm{He}$ added that drawing out the limited resources of the world specifically those of developing countries bears a negative impact. He stressed that

Tapping the limited resources of our world-particularly those of the developing nations simply to fuel consumerism, is disastrous. If it continues unchecked, eventually we will all suffer. We must respect the delicate matrix of life and allow it to replenish itself.(Universal Responsibility and Our Global Environment, 1992) [26]

This concern may be attributed to His Holiness' perception of the environment, which is influenced by the Buddha's teaching of safeguarding the life of all living beings by allowing Mother Earth to regenerate or replenish herself. He believed in the introduction of pollution prevention practices to limit damage to the environment, such as installing different equipment or technology, or changing raw materials or staff routines, that may be incorporated into any industrial operation. He is very much cognizant of the fact that it is possible to reduce environmental pollution without destroying industries or economies through the adoption of common preventive techniques. These techniques include the following: materials or feedstock substitution, product design or reformulation, equipment or process modification, spill and leak prevention, on-site reuse, recycling or recovery, inventory management or purchasing techniques, and good operating practice or training (Bennett, et al. 2018) 
[27]. Thus, it can be gleaned from His Holiness' words that each and every individual must consider himself or herself responsible and accountable for safeguarding the planet's regenerative capacities, and this is possible only by the avoidance of unnecessary consumption of the Earth's resources. If people have the capacity to destroy Mother Earth, so too do they have the capacity to protect her. By respecting the planet's limitations and giving it ample time to regenerate and heal itself, the safeguarding of Earth's regenerative capacities and sustainability may be attained.

\section{EnVironmental Sustainability ManifeSted in THE SElections}

His Holiness, the 14th Dalai Lama gave importance to Mother Earth's ecology by shaping an outline that served as a blueprint for the preservation of the planet. This he achieved through his teachings regarding reconciliation of environmental demands, social equity demands, and economic demands, all of which point to an overall sustainability of Mother Earth's resources.

\subsection{Ecological Sustainability Manifested in the Selections with Regard to Reconciliation of Environmental Demands}

His Holiness, the $14^{\text {th }}$ Dalai Lama referred to the planet's mountains as a rich source of natural resources, and in one of his works claimed the mountains of Tibet to be valid proof of man's failure to reconcile environmental demands. In the particular passage, he directly suggested that massive floods experienced by India and China were caused, in part, by the deforestation of the Tibetan mountain ranges that took place following China's invasion of Tibet. He noted that

In these stores of natural treasure our doctors found many of the precious herbs and plants from which they compounded their medicines, while nomads found rich pasture for their animals, so crucial to the Tibetan economy. But of even wider-ranging impact, the Land of Snow's mountains are the source of many of Asia's great rivers. The recent massive floods on the Indian sub-continent and in China can be attributed, in part, to the massive deforestation and environmental destruction that has followed China's violent occupation of Tibet. (An Essay on Mountains, 1992) [22]

It can be gleaned from the author's statement that this obvious failure to reconcile the environmental demands of the mountain ranges led to further environmental destruction. His Holiness, the $14^{\text {th }}$ Dalai Lama stressed that the desire to act must be heartfelt, and that these feelings towards the preservation of nature can be generated through developing a sense of responsibility toward all life on Earth. He noted that

These days when we talk about preservation of the environment, whether we mean the wildlife, forests, oceans, rivers or mountains, ultimately the decision to act must come from our hearts. So, the key point, I think, is for all of us to develop a genuine sense of universal responsibility, not only towards this beautiful blue planet that is our home, but also towards the innumerable sentient beings with whom we share it. (An Essay on Mountains, 1992) [22]

With a clear-cut definition of this problem, the author added an insight into how people can take hold of the issue. He was absolutely convinced that by developing a greater concern for the wellbeing of future generations and a greater sense of universal responsibility they can lay the foundations necessary to ensure the equitable use of natural resources and the proper care of the environment. He stated his belief that

To meet the challenge of our times, human beings will have to develop a greater sense of universal responsibility. Each of us must learn to work not for his or her self, family or nation, but for the benefit of all mankind. Universal responsibility is the real key to human survival. It is the best foundation for world peace, the equitable use of natural resources and through concern for the future generations, the proper care of the environment. (Universal Responsibility and Our Global Environment, 1992) [26]

This perception on ecological sustainability in line with reconciliation of environmental demands may be attributed to His Holiness, the $14^{\text {th }}$ Dalai Lama's conviction that ecological degradation is fast overtaking the world, including Tibet. He is very much convinced that if people do not make a concerted effort, with a genuine sense of universal responsibility, then they will see a continuation of the gradual breakdown of the fragile ecosystems that support life on Earth, resulting in an irreversible 
and irrevocable degradation of the planet. Today, what humankind needs to develop is a holistic approach towards problem solving combined with a genuine sense of universal responsibility, based on love and compassion. Indeed, Mother Earth is teaching humankind a lesson in universal responsibility, and this responsibility is the real key to human survival. This he believed is the best foundation for the equitable use of the Earth's natural resources and the proper care of the environment. For him, the Earth acts like a mother to all people, and, like children, they are dependent on her. Unless humankind works together, no solution can be found. From his statements, it can be gleaned that the author believes the sustainability of Earth's natural resources can only be achieved if mankind is able to effectively determine and reconcile the demands of the environment and its own needs.

\subsection{Ecological Sustainability Manifested in the Selections with Regard to Reconciliation of Social Equity Demands}

It is noteworthy to mention that in terms of ecological sustainability with regard to reconciliation of social equity concerns, His Holiness, the $14^{\text {th }}$ Dalai Lama pinpointed his concerns and offered possible solutions that aim to address these demands for social equity in a broader context. In a particular passage, he cited

We have to accept this. If we unbalance Nature, humankind will suffer. Furthermore, as people alive today, we must consider future generations: a clean environment is a human right like any other. It is therefore part of our responsibility towards others to ensure that the world we pass on is as healthy, if not healthier, than when we found it. This is not quite such a difficult proposition as it might sound. For although there is a limit to what we as individuals can do, there is no limit to what a universal response might achieve. It is up to us as individuals to do what we can, however little that may be. Just because switching off the light on leaving the room seems inconsequential, it does not mean that we should not do it. (A Clean Environment is a Human Right, 1990) [28]

Moreover, he added that

The problems we face today - violent conflicts, destruction of Nature, poverty, hunger, and so on - are mainly problems created by humans. They can be resolved - but only through human effort, understanding and the development of a sense of brotherhood and sisterhood. To do this, we need to cultivate a Universal Responsibility for one another and for the planet we share, based on a good heart and awareness. (A Clean Environment is a Human Right, 1990) [28]

This concept can be understood in another passage, wherein the author reminded human beings that a concerted effort of millions of people certainly has a significant impact.

As far as the individual is concerned, the problems resulting from our neglect of our natural environment are a powerful reminder that we all have a contribution to make. And while one person's actions may not have a significant impact, the combined effort of millions of individuals' actions certainly does. (The Natural World, 1999) [21]

Furthermore, he underscored that individual differences in fields of practice such as in science and religion should not undermine the general objective of humanity as a whole.

My plea is that we bring our spirituality, the full richness and simple wholesomeness of our basic human values, to bear upon the course of science and the direction of technology in human society. In essence, science and spirituality, though differing in their approaches, share the same end, which is the betterment of humanity. At its best, science is motivated by a quest for understanding to help lead us to greater flourishing and happiness. In Buddhist language, this kind of science can be described as wisdom grounded in and tempered by compassion. Similarly, spirituality is a human journey into our internal resources, with the aim of discovering how to live according to the highest possible idea. This too is the union of wisdom and compassion. (Science, Spirituality and Environment, 2005) [29]

This perception on ecological sustainability in line with reconciliation of social equity demands may be ascribed to His Holiness' belief in scientific and technological development that improves the total quality of life, both the current as well as the future, in a way that maintains the ecological processes on which life depends. Ecological sustainability includes the enhancement of individual and 
community well-being and welfare by following a path of economic development that safeguards the welfare of the future generations; the provision for equity within and between generations; and the protection of biological diversity and the maintenance of essential processes and life support systems. It can be noticed that the author's insight as regards ecological sustainability clearly stated the interdependence of man and society and the collective effort of institutions, notwithstanding ideological differences, in rebuilding a world where the society's need for balance and general prosperity are put into perspective. Thus, if humankind has a genuine sense of universal responsibility, as the central motivation and principle, then from that direction their relationship with the environment will be well-balanced. Similarly, with every aspect of relationships, their relations with their neighbors, their community and their fellow countrymen will also be balanced from that direction, which may eventually result in the maintenance of a balanced way of life.

\subsection{Ecological Sustainability Manifested in the Selections with Regard to Reconciliation of Economic Demands}

In relation to ecological sustainability with regard to the reconciliation of economic demands, His Holiness, the $14^{\text {th }}$ Dalai Lama himself favored a sustainable economic growth, provided that the people's ethical values are given priority.

I hope I have made the case that one can take science seriously and accept the validity of its empirical findings without subscribing to scientific materialism. I have argued for the need for and possibility of a world view grounded in science, yet one that does not deny the richness of human nature and the validity of modes of knowing other than the scientific. I say this because I believe strongly that there is an intimate connection between one's conceptual understanding of the world, one's vision of human existence and its potential, and the ethical values that guide one's behavior. How we view ourselves and the world around us cannot help but affect our attitudes and our relations with our fellow beings and the world we live in. This is in essence a question of ethics.

Scientists have a special responsibility, a moral responsibility, for ensuring that science serves the interests of humanity in the best possible way. What they do in their specific disciplines has the power to affect the lives of all of us. (Science, Spirituality and Environment, 2005) [29]

The afore cited line may be attributed to His Holiness' strong conviction of the importance of being able to understand that while ecological advances have played a vital role in improving the welfare of society, man must not overlook the fact that scientific research more often than not has been initiated to satiate materialistic interests.

It is not at all wrong for humans to use nature to make useful things, but we must not exploit nature to make useful things, but we must not exploit nature unnecessarily. It is good to live in a house, to have medicines, and to be able to drive somewhere in a car. In the right hands, a machine is not a luxury, but something very useful. A camera, for example, can be used to make pictures that promote understanding.

But everything has its limit. Too much consumption or effort to make money is no good.(Universal Responsibility and the Environment, 1990) [17]

He stressed that human greed for monetary gain, as seen in profit-oriented actions without adherence to humanitarian values, comes at the expense of stretching the planet's threshold for sustainability. $\mathrm{He}$ added that the present actions of humans show a blatant "lack of respect" for the future inhabitants who will inherit a planet with depleted resources. Thus, he emphasized that people must strive for alternatives to the culture of consumerism that is so destructive to themselves and to their planet [29]. His Holiness also stated that the earth can provide ample and sustainable resources for future generations only if the present generation cares enough for nature.

The environment is very important not only for this generation but also for future generations. If we exploit the environment in extreme ways, even though we may get some money or other benefit from it now, in the long run we ourselves will suffer and future generations will suffer. (Ecology and the Human Heart, 1990) [20]

This perception on ecological sustainability in line with reconciliation of social equity demands may be attributed to His Holiness' belief in the improvements made by humankind in line with their 
economic conditions. But instead of being contented with their lives and becoming better human beings, it seems that in matters of making money and gaining material things, people tend to stretch their limits, even making endless sacrifices. Such limitless pursuit of materials things, eventually, causes unwanted and unexpected problems. If people's economic condition improves, they must use the money for personal, social, and economic development as well as to further generate warmheartedness towards others. He believed that for hundreds of years, people thoughtlessly consumed the resources of the world as if there were no end to them. They failed to realize that unchecked consumerism was disastrous for both the environment and social welfare. Now, both individuals and governments are seeking a new ecological and economic order. As to whether the global economic crisis has brought about a greater sense of responsibility, His Holiness said that the reality is that people now have a global economy. Whether, they like it or not people have to approach it with a sense of global responsibility. He repeated that in a similar way, preservation of the environment and dealing with global climate change requires that people put the global interest before local or national interest.

\subsection{Teachings on Environmental Stewardship Drawn from Analysis of The 14th Dalai Lama's Works Which Shall Benefit the Students}

In addition to the aforecited teachings on environmental sustainability manifested in the selected writings of His Holiness, the $14^{\text {th }}$ Dalai Lama, it is also significant to note that the author included in his teachings a few vital points which appeal directly to present students as future torch bearers of humanity. The author directly called for a resolution relative to the most difficult and profoundly frightening challenge humankind currently faces. Life on earth is threatened by human activities that lack commitment to humanitarian values. The stage has now been reached where Mother Earth can no longer accept humankind's behavior in silence. The problems caused by environmental disasters can be seen as her response to their irresponsible behavior. Mother Earth is warning people that there are limits even to her tolerance.

His Holiness called for environmental stewardship. This stewardship is associated with individuals and networks of actors with diverse motivations and levels of capacity to protect, care for and responsibly use the environment in pursuit of environmental and/or social outcomes in different social-ecological contexts [27]. Without them, it would be hard to attain sustainability in the increasing industrially-based world.

Broadly, environmental education means learning to maintain a balanced way of life. Even if humankind would, there are now so many people on Earth that it could struggle to sustain such a growing population for long. People can share the earth and take care of it together, rather than trying to possess it, destroying the beauty of life in the process. In order to succeed in the protection and conservation of the environment, it is essential to bring about an internal balance within human beings themselves. The abuse of the environment, which has resulted in such harm to the human community, arose out of their obliviousness to the interdependence of living things and the environment. It is essential to help people to understand this. It is also important to teach people that the environment has a direct bearing on their own lives.

In the first place, people must strive to overcome these states of mind by developing an awareness of the interdependent nature of all phenomena, an attitude of wishing not to harm other living creatures and an understanding of the need for compassion. Because of the interdependent nature of everything, people cannot hope to solve the multifarious problems with a one-sided or self-centered attitude. History shows how often in the past people have failed to cooperate and the consequences of that noncooperation. Humankind's failures in the past are the result of ignorance of its own interdependence in nature. What is needed now is a holistic approach towards problem solving combined with a genuine sense of universal responsibility based on love and compassion.

To pursue growth properly, we need to renew our commitment to human values in many fields. Political life, of course, requires an ethical foundation, but science and religion, as well, should be pursued from a moral basis. Without it scientists cannot distinguish between beneficial technologies and those which are merely expedient. The environmental damage surrounding us is the most obvious result of this confusion. In the case of religion, it is particularly necessary.(Universal Responsibility and Our Global Environment, 1992) [26] 
He averred that

The purpose of religion is not to build beautiful churches or temples, but to cultivate positive human qualities such as tolerance, generosity and love. Every world religion, no matter what its philosophical view, is founded first and foremost on the precept that we must reduce our selfishness and serves others. Unfortunately, sometimes in the name of religion, people cause more quarrels than they solve. Practitioners of different faiths should realize that each religious tradition has immense intrinsic value as a means for providing mental and spiritual health. (Universal Responsibility and Our Global Environment, 1992) [26]

Furthermore, the author called for education as a methodical environmental program associated with the human mind, the human heart, and the environment, which are inseparably linked together. In this sense, he underscored that environmental education will help to generate both the understanding and love that students need to create the best opportunity there has ever been for peace and lasting coexistence. In addition to his teachings that call for every individual to take into account a certain level of ownership of responsible stewardship, even more enticing for today's youth is the author's message on science and religion. The author clearly expressed high hopes in the reconciliation of religion and science, as he cited the achievement of a certain level of compatibility of these two previously competing concepts. These can all prove beneficial for students in a way that it suggests that with a unified perspective and collective stewardship, world peace and ecological preservation can be an achievable goal.

Taking into account each and every insight provided by His Holiness, it is therefore important to give emphasis to the spiritual conditioning required for every student to achieve the necessary level of awareness for the author's insights to serve their purpose, and imbibe the author's spirit and carry forward his legacy by practicing daily the pro-environment principle.

\section{CONCLUSIONS AND RECOMMENDATIONS}

The selected writings of His Holiness, the $14^{\text {th }}$ Dalai Lama consider the direct relationship of man with his environment, clearly outlining a simple solution that will serve as man's focal point in resolving global conflict, and the attainment of a sustainable ecosystem. Ecological concerns were reflected in His Holiness' selected works in terms of appreciating Earth's bounty and beauty, respecting Earth and life in all its diversity, caring for community life, and safeguarding Earth's regenerative capacities. Ecological sustainability was manifested in the author's works with regard to reconciliation of environmental demands, social equity demands and economic demands. Teachings on ecological stewardship which shall benefit students were also drawn from the author's works. Taking into account each and every insight provided by the $14^{\text {th }}$ Dalai Lama in the aforecited sections, it is therefore important to give emphasis to the spiritual conditioning required for every person to achieve the necessary level of awareness, particularly awareness of the needs of Mother Nature, for the author's insights to serve their purpose.

From the foregoing findings and conclusions, this study therefore offers the following recommendations: that academicians particularly in the field of literature and philosophy consider the inclusion of His Holiness, the $14^{\text {th }}$ Dalai Lama's teachings with this study as an example and guide, in order for the lessons on environmental and ecological stewardship to be inculcated in every student's awareness. It is also recommended that the faculty be able to utilize the existing methods, techniques, and materials for instruction in order for these insightful teachings to be able to appeal to the students' consciousness. In addition, a strategic utilization of the advantages of the worldwide web or the internet as well as social media must be considered, as the youth of the present generation, especially the students, currently benefit from a plethora of accessible information and the ease of dissemination as afforded to them by the said technology.

\section{ACKNOWLEDGMENTS}

The researcher wishes to express her personal thanks and appreciation to those who helped make this humble work a reality. First and foremost, she wishes to thank God, for inspiring her during the writing process. To Dr. Tirso A. Ronquillo, the Batangas State University President and the other University officials most especially to Dr. Erma B. Quinay, the Vice President for Academic Affairs; Engr. Albertson D. Amante, the Vice President for Research, Development and Extension Services; 
and Prof. Enrico M. Dalangin, the BatStateU ARASOF Nasugbu Executive Director, for the motivation that helps hasten the completion of this study. To Mr. David William R. Wright for the wonderful job editing the manuscript. To Mr. Thaakor Pathak, for his wisdom that drew up essential and relevant dimensions in this research. To the pool of writers whose works were included in this study for posterity, for their emboldened wisdom in every page of this research. To all of you, the researcher owes her deep gratitude.

\section{REFERENCES}

[1] Vena, Christopher J. (2009)Beyond Stewardship: Toward an Agapeic Environmental Ethic. Unpublished Thesis: Marquette University, 2009.

[2] USA International Business Publications (2007) Philippines Country Study Guide - Strategic Information and Developments. Washington DC: USA.

[3] UNEP.org Website (2015) What is UNEP?;Retrieved from: http://www.unep.org/newscentre/default.aspx? DocumentID=2711HYPERLINK "http://www.unep.org/newscentre/default.aspx?DocumentID=2711\&ArticleI; date retrieved: 02/17/2016.

[4] UNEP.org Website (2016) The United Nations Environment Programme and the 2030 Agenda: Global Action for People and the Planet; url: http://www.unep.org/pdf/UNEP_and_the_2030_Agenda.pdf; date retrieved: 02/17/2016.

[5] Ogundokun, Sikiru Adeyemi (2014)Literature as a Reflection on Socio-Political Realities: An Examination of Three Nigerian Writers. Retrieved from: http://www.theartsjournal.org/index.php/ site/article/view/300; date retrieved: 08/15/2015.

[6] Jacobs, Allan (2011) His Holiness the Dalai Lama: Infinite Compassion for an Imperfect World. Watkins Publishing, London, United Kingdom.

[7] Dalailama.com Website (2016) Brief Biography; Retrieved from: http://www.dalailama.com/biography/ significance; date retrieved: 02/17/2016.

[8] Wisdompubs.org Website (2016) His Holiness The Dalai Lama; Retrieved from: http://www.wisdompubs .org/author/his-holiness-dalai-lama; date retrieved: 02/18/2016.

[9] Suter, W. Newton (2012). Introduction to Educational Research. University of Arkansas at Little Rock Sage Publications, Inc.

[10] Ary, Donald, Lucy Cheser Jacobs, Asghar Razavieh, Christine K. Sorensen (2006). Introduction to Research in Education. Wadworth: Belmont, California, USA.

[11] Patton, M. Q. (2002). Qualitative Research and Evaluation Methods. Thousand Oaks, California, USA: Sage.

[12] McMillan, S. J. (2000). The Microscope and the Moving Target: The Challenge of Applying Content Analysis to the World Wide Web. Journalism and Mass Communication Quarterly, 77(1), 80-98.

[13] Stott, M. (2014). What are the Literary Standards in Literature?;Retrieved from: http://artsliterature.blurtit.com/1120166/what-are-the-literary-standards-in-literature; date retrieved: 12/31/2014.

[14] Dalai Lama (2005). His Holiness, the $14^{\text {th }}$ Dalai Lama on Environment-Collected Statements 1987-2017: Mother Sentient Being. Environment \& Development Desk. Tibet Policy Institute.

[15] Dalai Lama (1990). His Holiness, the 14 ${ }^{\text {th }}$ Dalai Lama on Environment-Collected Statements 1987-2017: A Clean Environment is a Human Right. Environment \& Development Desk. Tibet Policy Institute.

[16] Dalai Lama (1999). His Holiness, the 14 ${ }^{\text {th }}$ Dalai Lama on Environment-Collected Statements 1987-2017: Thinking Globally: A Universal Task. Environment \& Development Desk. Tibet Policy Institute.

[17] Dalai Lama (1990). His Holiness, the $14^{\text {th }}$ Dalai Lama on Environment-Collected Statements 1987-2017: Universal Responsibility and the Environment. Environment \& Development Desk. Tibet Policy Institute.

[18] Dalai Lama (1992). His Holiness, the $14^{\text {th }}$ Dalai Lama on Environment-Collected Statements 1987-2017: A Buddhist Concept of Nature. Environment \& Development Desk. Tibet Policy Institute.

[19] Dalai Lama (1987). His Holiness, the $14^{\text {th }}$ Dalai Lama on Environment-Collected Statements 1987-2017: An Ethical Approach to Environmental Protection (1986). Environment \& Development Desk. Tibet Policy Institute.

[20] Dalai Lama (1990). His Holiness, the $14^{\text {th }}$ Dalai Lama on Environment-Collected Statements 1987-2017: Ecology and the Human Heart. Environment \& Development Desk. Tibet Policy Institute.

[21] Dalai Lama (1999). His Holiness, the $14^{\text {th }}$ Dalai Lama on Environment-Collected Statements 1987-2017: The Natural World (1999). Environment \& Development Desk. Tibet Policy Institute.

[22] Dalai Lama (1992). His Holiness, the $14^{\text {th }}$ Dalai Lama on Environment-Collected Statements 1987-2017: An Essay on the Mountains (1992). Environment \& Development Desk. Tibet Policy Institute. 
[23] Dalai Lama (2013). His Holiness, the $14^{\text {th }}$ Dalai Lama on Environment-Collected Statements 1987-2017: Universal Responsibility \& the Global Environment: An Environmental Summit (2013). Environment \& Development Desk. Tibet Policy Institute.

[24] Dalai Lama (1991). His Holiness, the $14^{\text {th }}$ Dalai Lama on Environment-Collected Statements 1987-2017: Caring for the Earth (1991). Environment \& Development Desk. Tibet Policy Institute.

[25] Dalai Lama (2007). His Holiness, the 14 ${ }^{\text {th }}$ Dalai Lama on Environment-Collected Statements 1987-2017: Politics and Environment: An Interview (2007). Environment \& Development Desk. Tibet Policy Institute.

[26] Dalai Lama (1992). His Holiness, the $14^{\text {th }}$ Dalai Lama on Environment-Collected Statements 1987-2017: Universal Responsibility \& the Global Environment (1992). Environment \& Development Desk. Tibet Policy Institute.

[27] Bennett, Nathan J., Tara S. Whity, Elena Finkbeiner, Jeremy Pittman, Hannah Bassett, Stefan Gelcich and Edward H. Allison (2018). Environmental Stewardship: A Conceptual Review and Analytical Framework. Environmental Management. Springer

[28] Dalai Lama (1990). His Holiness, the $14^{\text {th }}$ Dalai Lama on Environment-Collected Statements 1987-2017: A Clean Environment is a Human Right. Environment \& Development Desk. Tibet Policy Institute.

[29] Dalai Lama (2005). His Holiness, the $14^{\text {th }}$ Dalai Lama on Environment-Collected Statements 1987-2017: Science, Spirituality and Environment (2005). Environment \& Development Desk. Tibet Policy Institute.

[30] Dalai Lama (2016). His Holiness, the $14^{\text {th }}$ Dalai Lama on Environment-Collected Statements 1987-2017: His Holiness Join 270 Religious Leaders to Sign Interfaith Climate Statement (2016). Environment \& Development Desk. Tibet Policy Institute.

\section{AUTHOR'S BIOGRAPHY}

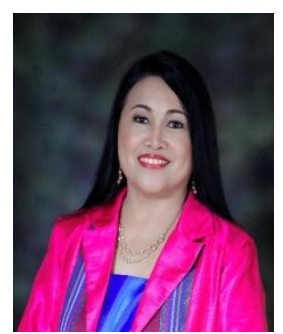

Maria Luisa A. Valdez, earned a Doctor of Philosophy degree with a specialization in English from the Batangas State University (BatStateU), Philippines. She has published several researches in reputable international refereed journals and presented papers on local, national and international research forums. Likewise, she is an editorial board member and a peer reviewer of various international refereed journals. She was hailed as the Best Research Presenter and her papers won the Best Research Paper Awards in local and international research conferences. Her research interest centers on education, philosophy, humanities and social sciences specifically on contemporary social issues like peace education, gender equality, and environmental issues manifested in the selected contemporary literary works in English. She is currently a professor in BatState $U$ and a visiting professor of the Thai Nguyen University (TNU) International Training and Development Center (ITDC), Socialist Republic of Vietnam.

Citation: Maria Luisa A. Valdez, Ph.D. "Reflections on Environmental Concern and Sustainability Manifested in the Selected Works of the 14th Dalai Lama". International Journal on Studies in English Language and Literature (IJSELL), vol 6, no. 7, 2018, pp. 32-47. doi:http://dx.doi.org/10.20431/23473134.0607005 .

Copyright: (C) 2018 Authors. This is an open-access article distributed under the terms of the Creative Commons Attribution License, which permits unrestricted use, distribution, and reproduction in any medium, provided the original author and source are credited. 